\title{
O RELATÓRIO FIGUEIREDO E AS VIOLAÇÕES DOS DIREITOS INDÍGENAS NAS PÁGINAS DO JORNAL DO BRASIL (1965- 1968)
}

\author{
RAYANE BARRETO DE ARAÚJO ${ }^{1}$
}

UFRRJ

\begin{abstract}
RESUMO: Este trabalho tem como objetivo principal apresentar as representações de violações dos direitos indígenas no Jornal do Brasil durante os anos de 1965-1968, e do texto final da Comissão de Inquérito de 1967 do Ministério do Interior, cujo relatório, "redescoberto" durante as pesquisas da Comissão Nacional da Verdade, foi apelidado de "Relatório Figueiredo". Ao partir de uma análise do discurso de notícias, matérias e editoriais do JB no recorte escolhido, articulando-a à bibliografia sobre o tema, propõe-se mostrar as perspectivas que guiavam as narrativas do jornal sobre os indígenas e sobre o Serviço de Proteção aos Índios (SPI), instituição indigenista do período. Desta forma, o foco do presente artigo recai sobre as representações acerca dos indígenas e dos violadores, os tipos de violações veiculados e sua abrangência, as repercussões da situação dos povos indígenas entre jornais internacionais, e como o JB compreendia este processo de violações e o trabalho da comissão. Além disso, será apresentado como um padrão discursivo que tinha como foco a responsabilidade de funcionários do SPI nos casos de violações e corrupções, deslocados quase sempre da responsabilidade dos governos ditatoriais, foi se consolidando no contexto das investigações.
\end{abstract}

PALAVRAS-CHAVE:Relatório Figueiredo; Jornal do Brasil; indígenas; violações de direitos indígenas; ditadura militar.

ABSTRACT: The main objective of this work is to present the representations of violations of Indigenous rights in the Brazilian newspaperJornal do Brasil during the years 1965-1968, and inthe final text of the Committee of Inquiry of the Ministry of the Interior (1967), thereport of which, nicknamed "Figueiredo Report", was "rediscovered" by the National Commission of Truth. Based on a speech analysis of thenews, articles and editorials in the chosen section of Jornal do Brasil, and articulating it withthe bibliography on the theme, we intend to show the perspectives that guided the narratives about the Indigenous people and the Indian Protection Service (SPI, the indigenist institution of the period) in the newspaper. The focus of this article is on the representations of Natives and their aggressors, the kindsof violations and their scope, the repercussions of the situation of Indigenous peoples of Brazil in the international newspapers and how JB understood this process of violations and the work of the committee. In addition, we aim at presenting how a discursive pattern focused on the responsibility of SPI officials in cases of violations and corruption, usually unrelated to the responsibility of dictatorial governments, has been consolidated in the context of the investigations.

${ }^{1}$ Bacharel e licenciada em História pela Universidade Federal do Rio de Janeiro. Mestranda no Programa de Pós-Graduação em História da Universidade Federal Rural do Rio de Janeiro, onde é orientada pela Prof ${ }^{a}{ }^{a}{ }^{a}$ Vânia Losada Moreira. É bolsista Capes.E-mail: rayane.barreto@ hotmail.com. 
KEYWORDS:Figueiredo Report; Jornal do Brasil; Indigenous; violations of Indigenous rights; military dictatorship.

\section{Introdução}

Em 2012 foi sancionada pela presidenta Dilma Rousseff a Lei $\mathrm{N}^{\circ}$ 12.528, de criação de uma Comissão Nacional da Verdade (CNV), que teria por função investigar as violações dos direitos humanos cometidas entre os anos de 1946-1988 no Brasil, com o objetivo de "efetivar o direito à memória e à verdade histórica e promover a reconciliação nacional" (BRASIL,2011). A partir da demanda de grupos indígenas para que a temática da violência a essa população fosse incorporada às pesquisas, no ano de 2014, através do relatório de conclusão das investigações, a CNV2 tornou públicas as marcas da violência da ditadura militar sobre os povos indígenas brasileiros.

O relatório Violações de direitos humanos dos Povos Indígenas marca o reconhecimento oficial do Estado brasileiro sobre sua participação nas violações dos direitos indígenas, incluindo também violações dos direitos humanos, não apenas no período de ditadura militar, mas durante grande parte do período republicano. Além disso, visto que tornou público documentos antes secretos ou "desaparecidos", a CNV favoreceu a consolidação de um campo de estudos que tem como preocupação pesquisar as violências cometidas contra os povos indígenas, as violações de seus direitos e suas formas de resistência durante a ditadura militar (1984-1985)3.

\footnotetext{
${ }^{2}$ No caso dos indígenas, não havia uma proposta inicial por parte da CNV sobre investigações de violações de seus direitos. Essas só foram incorporadas após a mobilização e pressão do próprio movimento indígena, que entrou em contato com o coordenador do grupo Tortura Nunca Mais e colaborador da Comissão Nacional da Verdade, Marcelo Zelic.

3 No período anterior à Comissão Nacional da Verdade, poucas produções tinham como objeto especificamente os povos indígenas durante a ditadura militar. Podemos mencionar obras que tratam de um período mais amplo sobre a luta indígena ou que apresentam maior preocupação com a política indigenista republicana: o livro de Seth Garfield (2009) sobre a luta dos Xavante entre 1937 e 1988, o livro de José Mauro Gagliardi (1989) sobre os indígenas na República, de Mércio Pereira Gomes (1991) Os índios e o Brasil, a coletânea de artigos de Manuela Carneiro da Cunha (2012) a respeito da política indigenista no Brasil, a obra clássica de Antônio Souza Lima (1995) que trata da política indigenista republicana, a dissertação de Anna Maria Costa (2002) sobre a resistência dos Nambiquara entre as
} 
O relatório final sobre os povos indígenas - que foi construído a partir de uma ampla base documental, bibliográfica e testemunhalterminou por estimar que mais de 8.500 indígenas foram mortospor ações violentas, direta ou indiretamente promovidas pelo Estado brasileiro entre 1946-1988. A maior parte dessas violações estaria concentrada nos anos de ditadura militar, período no qual o caráter autoritário dos governos expressava-se também nos planos de desenvolvimento econômico para o país.

O desenvolvimentismo dos governos militaresesteve na base das violações dos direitos indígenas, tendo em vista que foram articulados à própria política indigenista (DAVIS, 1978; HECK, 1996; CNV, 2014). Além da negligência sanitária nos contatos ou na assistência, o avanço das frentes econômicas de expansãode agropecuárias e da indústria favorecido pelossubsídios oferecidos pelo governo -,a manutenção da renda indígena, projetos de infraestrutura estatal, e o indigenismo autoritário, foram condições para uma ofensiva sobre as terras indígenas, estimulando um processo de violência contra esses povos.A violência ocorria principalmente pela invasão de terras, deslocamentos forçados, assassinatos, torturas, prisões arbitrárias e expansão de epidemias que vitimaram inúmeros povos indígenas (CNV, 2014).

Como direitos indígenas, compreendemos não apenas o direito ao uso e o usufruto das terras que ocupavam, estabelecidos pelas constituições federais brasileiras desde 1934, mas também os próprios Direitos Humanos, como o direito à dignidade, igualdade, liberdade, à vida e segurança pessoal, ratificados pela Assembleia Geral das Nações Unidas, na Declaração Universal de 1948. No período ditatorial, as

décadas de 1940 e 60, e a coletânea de artigos organizada por João Pacheco de Oliveira (1998) sobre indigenismo e territorialização. Das obras anteriores à CNV, que focaram na política indigenista, nos impactos dos projetos de desenvolvimento sobre as povosindígenas e nas violações de seus direitos no período ditatorial, podemos mencionar o livro do antropólogo David Price (1989) sobre os impactos dos projetos de desenvolvimentos sobre os Nambiquara, e a tese de EgonHeck (1996) a respeito da política indigenista dos governos militares. Os trabalhos mais recentes, produzidos após o início das pesquisas da $\mathrm{CNV}$, vêm apresentando uma maior preocupação com a violação dos direitos indígenas e, em grande parte, têm se debruçado sobre o Relatório Figueiredo. Destacamos algumas dessas produções acadêmicas, teses e dissertações mais recentes: a dissertação de mestrado de Rodrigo Lins Barbosa (2016) sobre crimes e corrupção no SPI e na Funai, a tese de doutorado de Antônio Jonas Dias Filho (2015) que trata dos presídios indígenas na ditadura, a dissertação pioneira de Elena Guimarães (2015) sobre o Relatório Figueiredo, e a dissertação de mestrado de Eduardo Silva Filho (2015) que trata da resistência dos Waimiri-Atroari do período ditatorial até 2014. Uma obra também recente sobre a resistência indígena na ditadura, que oferece um panorama sobre as violações de direitos e a resistência, é o livro "Os fuzis e as flechas", de 2017, do jornalista Rubens Valente. 
violações desses direitos estiveram associadas ao não cumprimento pelo Estado brasileiro dos deveres das instituições indigenistas para com os indígenas brasileiros, sobretudo o de proteção e assistência, conforme estabelecidos nos decretos de criação das instituições responsáveis que funcionaram nesse período 4 .

Duas instituições indigenistas funcionaram durante a ditadura e ambas foram aparelhadas pelos interesses de grupos econômicos (DAVIS, 1978; HECK, 1996; GUIMARÃES, 2015). A primeira, o Serviço de Proteção aos Índios (SPI) havia sido criado em 1910 como órgão indigenista $^{5}$ (LIMA,1995) do Estado brasileiro. Era incumbido da assistência e proteção aos indígenas, subordinado ao Ministério da Agricultura, e responsável pela política de tutela, até a sua extinção em 1967 por Costa e Silva. Em dezembro de 1967, o Decreto n 5.371 autoriza o governo federal a criar a Fundação Nacional do Índio (Funai), que teria as mesmas funções que o antigo órgão, subordinada ao Ministério do Interior (GAGLIARDI, 1989; LIMA, 1995; RIBEIRO, 1996). A Funai permanece atualmente como a instituição indigenista do Brasilagora vinculada ao Ministério da Justiça.

Com o golpe de 1964, já nos primeiros anos de ditadura, uma política indigenista empresarial associada ao modelo econômico de retenção de gastos do governo de Castelo Branco foi implementada, impactando a forma de exploração das terras indígenas, voltando a produtividade dessa exploração para sustentar o próprio órgão:

\footnotetext{
${ }^{4}$ Nas constituições que estiveram em vigência no recorte aqui estudado - a Constituição de 1946 e a Constituição de 1967 - os direitos indígenas estavam assim estabelecidos: Constituição de 1946: "Art. 216 - Será respeitada aos silvícolas a posse das terras onde se achem permanentemente localizados, com a condição de não a transferirem."; Constituição de 1967: "Art. 186 - É assegurada aos silvícolas a posse permanente das terras que habitam e reconhecido o seu direito ao usufruto exclusivo dos recursos naturais e de todas as utilidades nelas existentes". Desde 1934 as constituições brasileiras estabeleceram os direitos dos indígenas. Os decretos de criação e de regulamentação - Decreto $\mathrm{n}^{\circ} 8.072$ de 1910 e Decreto n 10.652 de 1942 - do Serviço de Proteção aos Índios, definiam, entre outras obrigações, que o órgão teria por fim prestar assistência aos índios do Brasil, amparar-lhes a vida, velar pelos direitos vigentes, garantir a efetividade da posse dos territórios ocupados, respeitar a organização das diversas tribos e sua independência, exercer vigilância para que não fossem coagidos a prestar serviços para particulares e promover a punição de crimes cometidos contra índios. A lei de criação da Funai - Lei № 5.371 de 1967 - define entre as funções dessa instituição respeitar a vida do índio e as instituições tribais, garantir a posse e permanência nas terras que habitam e seu usufruto exclusivo, preservar o equilíbrio biológico e cultural do índio, promover a prestação de assistência médico-sanitária, e promover educação apropriada. ${ }^{5}$ Seguindo a perspectiva de Antônio Carlos Souza Lima, compreendemos como política indigenista as práticas de Estado direcionadas aos povos indígenas que ocupam o seu território.
} 
Os militares, que tomam o poder do Estado em 1964, enfrentam uma economia marcada por forte inflação, imprimindo uma política recessiva e concentradora. A questão indígena não ficaria alheia a [sic] nova política. O capitão-aviador Luiz Vinhas Neves assume o SPI, com a incumbência de dar-lhe auto-suficiência. Tal tarefa significava dar um caráter empresarial e desenvolvimentista ao órgão. 'Com as diretrizes que pretendo imprimir ao Serviço de Proteção aos Índios, dentro de um ano ele será auto-suficiente.' (Diário de Brasília, 24/07/64)"(HECK, 1996, p.74).

O ideal que guiava o SPI, e posteriormente a Funai, era o da necessidade da "integração" do indígena, assim como deveria ocorrer com os territórios que ocupavam. Conforme apresenta Elena Guimarães em sua dissertação pioneira sobre o Relatório Figueiredo recuperado pela CNV:

O pensamento dominante, o ideal desenvolvimentista, baseava-se na premissa de que os grupos indígenas deveriam ser rapidamente integrados, como força de trabalho de reserva ou como produtores de mercadorias, às economias regionais em expansão e às estruturas de classe rurais do Brasil (GUIMARÃES, 2015, p.35).

Nessa perspectiva "integracionista" e desenvolvimentista, a renda indígena, levada a sua constante utilização, gerou grande estímulo à corrupção, assim como a maior exploração das terras indígenas, do trabalho indígena, do patrimônio indígena, por civis e funcionários dos órgãos indigenistas. Essas práticas se tornaram tão recorrentes que denúncias, realizadas pela imprensa e por comissões de inquérito, que falavam sobre o envolvimento de funcionários do SPI em violações dos direitos indígenas, contribuíram para a crise e extinção do órgão em 1967, levandoà criação, em 1969, da Fundação Nacional do Índio (Funai) (DAVIS, 1978; HECK, 1996; GUIMARÃES, 2015). O resultado do golpe de 1964 foi a intensificação das pressões sobre terras indígenas, massacres e expansão de doenças (GAGLIARDI, 1989).

Nesse contexto que leva à crise do SPI, foi criada para investigar irregularidades na instituição a Comissão de Inquérito do Ministério do Interior, em 1967, presidida pelo procurador Jáder Figueiredo Correia. O 
texto do inquérito resultante das investigações da comissão do Ministério do Interior de 1967, recuperado nas pesquisadas da CNV em 2012, ficou conhecido como Relatório Figueiredo. A "redescoberta" do relatório final dessa comissão de inquérito, no Museu do Índio, em 2012, pelo pesquisador e representante do grupo Tortura Nunca Mais, Marcelo Zelic, trouxe à tona a complexidade da violência do Estado ditatorial contra os povos indígenas do país, quando analisado pela Comissão Nacional da Verdade.

No Relatório Figueiredo, que havia sido dado como perdido num incêndio do Ministério da Agricultura em 1967, foram relatados casos de corrupção no SPI, de torturas, assassinatos, vendas e arrendamentos ilegais de terras, escravização, exploração sexual de mulheres indígenas, e muitos outras ocorrências de violência cometidas contra pessoas indígenas por civis e funcionários do SPI (GUIMARÃES, 2015).

É possível que nos perguntemos: o fato do Relatório Figueiredo ter sido "esquecido" por todo esse tempo, tanto pela sociedade brasileira não-indígena quanto pela historiografia e os demais campos das Ciências Humanas, não seria resultado da sua não divulgação ou da censura da ditadura militar? Poderíamos incorrer ao erro de responder que sim, mas o levantamento de outra documentação sugere que tanto a Comissão de Inquérito quanto o conteúdo do seu relatório foram amplamente divulgados pela imprensa nacional e internacional. Apesar disso, um dos limites deste trabalho é conseguir dimensionar a circularidade destas informações entre a população brasileira e de outros países, tendo em vista que nos escapam, no momento, fontes que nos possibilitem compreender os alcances destas informações para além do campo jornalístico.

A análise dos jornais da época, assim como o relatório final da Comissão de Inquérito do Ministério do Interior de 1967 (Relatório Figueiredo), nos permitem observar que a violação dos direitos territoriais indígenas e dos direitos humanos daqueles povos não ocorreu apenas no período mais autoritário, após o $\mathrm{Al}-5$, que cerceou a liberdade de expressão e manifestação, além da suspensão do habeas corpus, que abria prerrogativa para o arbítrio.

Um dos veículos de comunicação que apresentou denúncias sobre o tratamento do SPI aos indígenas e se debruçou sobre os fatos 
investigados pela Comissão de Inquérito foi o Jornal do Brasil, órgão da grande imprensa e de ampla circulação no país. Dezenas de reportagens, notícias e editoriais foram produzidos abordando a situação dos indígenas naquele momento.

A análise do discurso de notícias, matérias e editoriais da qual resulta este artigo se baseia nos conceitos de discurso (MAINGUENEAU, 2005) e de representação (CHARTIER, 2002). De acordo com o linguista Dominique Maingueneau (2005), o discurso é uma organização situada para além da frase - submetido a regras vigentes num grupo social determinado. Ele é orientado, assume uma função atribuída pelo locutor, se desenvolve no tempo e se destina a algum lugar: é uma forma de ação sobre o outro, que visa transformar uma situação, e não ser apenas uma representação do mundo. Assim, o discurso está submetido a um contexto e a um sujeito, um EU, que se coloca como a fonte de referência - no caso deste trabalho, o Jornal do Brasil.

Segundo Roger Chartier (2002), os discursos são configurados por representações que correspondem a uma forma de ver e refigurar as coisas a partir dos interesses dos grupos que as forjam, e estão "sempre colocadas num campo de concorrências e/competições" (CHARTIER, 2002 , p.17) pelo poder e dominação. A representação é "ação" que tem como objetivo "a construção do mundo social" (CHARTIER, 2002, p.17).

$O J B$ antes, durante e depois da Comissão de Inquérito relatava a situação de violência e desassistência na qual encontravam-se parte dos indígenas brasileiros. Embora as representações( CHARTIER, 2002) sobre os indígenas fossem muitas vezes exotizadas, estereotipadas e, em alguns casos, exaltassem feitos da política indigenista, o jornal também cobrava do governo federal a resolução dos conflitos pela terra e a punição daqueles que cometiam crimes contra os indígenas. Os discursos (MAINGUENEAU, 2005) do JB oferecem, assim, subsídios para compreendermos melhor não apenas o posicionamento do jornal, mas as dimensões das violações dos direitos indígenas, a conjuntura de criação da Comissão de Inquérito do Ministério do Interior, o conteúdo do Relatório Figueiredo, e as expectativas e conflitos em torno da sua divulgação. 


\section{A Comissão de Inquérito de 1967 e o Relatório Figueiredo}

O relatório final da Comissão de Inquérito do Ministério do Interior de 1967, conhecido hoje por Relatório Figueiredo, foi amplamente divulgado na imprensa da época e recentemente "redescoberto" no contexto de investigações da Comissão Nacional (e estaduais) da Verdade. Ele resultou de investigações realizadas durante o ano de 1967 por uma Comissão de Inquérito criada pelo Ministro do Interior gal. Albuquerque Lima, presidida pelo procurador do Departamento Nacional de Obras Contra as Secas (DNOCS), Jáder de Figueiredo Correia. Figueiredo e a equipe da comissão percorreram diversos estados e dezenas de postos indígenas do SPI durante sete meses, a partir de julho de 1967, levantando documentações e testemunhos. Na conclusão das investigações, 20 volumes e 6.689 páginas foram entregues ao Ministro do Interior - só 19 dos quais existe hoje (GUIMARÃES, 2015).

O objetivo da Comissão de Inquérito, criada a partir da Portaria $\mathrm{n}^{\circ}$ 154/67, era averiguar irregularidades no âmbito do SPI. No entanto, o tratamento dispensado aos povos indígenas sob o poder tutelar (LIMA, 1995) do Estado também esteve na pauta das investigações. A descrição das irregularidades no SPI e a violência e desassistência que muitos indígenas sofriam ocupou centenas de páginas do relatório, assim como dos textos da imprensa.

A Comissão de Inquérito do Ministério do Interior de 1967 deu seguimento às investigações do ano de 1963, realizadas pela Comissão Parlamentar de Inquérito da Câmara dos Deputados, cuja parte da documentação foi anexada ao texto final do inquérito da Comissão de 1967, o Relatório Figueiredo. Denúncias de irregularidades no âmbito do SPI e investigações sobre órgão eram recorrentes. Foram abertos vinte e um inquéritos administrativos no SPI entre os anos de 1956 e 1963, embora alguns desses não tenham sido concluídos. O inquérito do Ministério do Interior foi arquivado em 1968, possivelmente devido ao Al-5 (GUIMARÃES, 2015), com a escalada do autoritarismo da ditadura.

No texto, Jáder Figueiredo comenta casos de corrupção no SPI e diferentes crimes cometidos contra a vida e o patrimônio de indígenas, 
por parte de funcionários do SPI ou com o conhecimento desses. Destaca também a articulação que servidores do órgão tinham com grupos econômicos interessados nas terras indígenas.

O documento, baseado em farta documentação e testemunhos, apresenta um quadro de miséria, doenças, massacres, torturas, invasões de terras, apropriação de renda e uma série de outros abusos cometidos contra os diferentes povos indígenas brasileiros. No relatório são arrolados crimes de nove tipos, que iam desde irregularidades administrativas e desvios orçamentários a crimes contra a pessoa do indígena e seu patrimônio:

Os demais são relativos a desvios financeiros e irregularidades administrativas, tais como adulteração de documentos, fraudes em processos de comprovação de contas, desvio de verba orçamentária, aplicação irregular de dinheiro público, omissões dolosas, admissões fraudulentas de funcionários e incúria administrativa. Dos crimes contra a propriedade do índio, são listados: usurpação do trabalho, apropriação e desvio de recursos oriundos do patrimônio indígena. A dilapidação do patrimônio indígena diz respeito à venda de gado, arrendamento de terras, venda de madeiras, exploração de minérios, venda de castanha e outros produtos de atividades extrativas e de colheita, venda de produtos de artesanato indígena, doação criminosa de terras, venda de veículos. Esta apropriação de recursos se dava a partir de atividades legalizadas, mas que eram feitas de forma irregular, praticadas por agentes em benefício próprio ou de terceiros.

E dos crimes contra a pessoa do índio, são descritos assassinatos, prostituição, sevícias, trabalho escravo e prática de espancamento e castigos (GUIMARÃES, 2015, p.28).

Como mencionado, ao texto final de 1967 foi incorporada a documentação da CPI de 1963, que versava sobre irregularidades no SPI e crimes contra indígenas ocorridos antes ou naquele período portanto, antes da ditadura militar - como foi o evento de assassinato em massa de indígenas da etnia Cinta-Larga no Mato Grosso em 1963 (GUIMARÃES, 2015). Entretanto, no Relatório Figueiredo há muitos outros acontecimentos de crimes contra indígenas presenciados pela 
própria comissão chefiada por Jáder Figueiredo, ou relatados por eles a ela, já ocorridos após o golpe de 1964.

O Relatório Figueiredo é um inquérito administrativo, portanto trata, sobretudo, de irregularidades e crimes cometidos por funcionários do Estado (GUIMARÃES, 2015). Esse pode ser um motivo pelo qual tanto o relatório quanto os jornais focassem mais nos crimes e irregularidades cometidos por funcionários do SPI, embora grande parte fosse cometida por civis ligados a grupos econômicos que possuíam interesse nas terras e mão-de-obra dos indígenas.

Impactado com o que viu, Jáder Figueiredo, chefe da comissão, escreve no relatório:

O índio, razão de ser do SPI, tornou-se vítima de verdadeiros celerados, que the impuseram um regime de escravidão e lhe negaram um mínimo de condições de vida compatível com a dignidade da pessoa humana.

É espantoso que existe na estrutura administrativa do País repartição que haja descido a tão baixos padrões de decência. E que haja funcionários públicos, cuja bestialidade tenha atingido tais requintes de perversidade. Venderam-se crianças indefesas para servir aos instintos de indivíduos desumanos. Torturas contra crianças e adultos, em monstruosos e lentos suplícios, a título de ministrar justiça (MINISTÉRIO DO INTERIOR, proc. no $4.483 / 68$, v. 20,p. 4.912 apud GUIMARÃES, 2015, p.61).

No volume 20 do documento final das investigações, o procurador relata o cenário que presenciou nas viagens pelo Brasil, apresentando com detalhes como os indígenas eram desrespeitados enquanto seres humanos. Um dos crimes recorrentes eram as torturas, dentre as quais ele descreve uma ocorrência do sistema da $7^{\text {a }}$ Inspetoria no Rio Grande do Sul, praticada pelos funcionários de postos indígenas do SPI na região:

O "tronco" era, todavia, o mais encontradiço de todos os castigos, imperando na $7^{a}$ Inspetoria. Consistia na trituração do tornozelo da vítima, colocado entre duas estacas enterradas juntas em ângulo agudo. As extremidades, ligadas por roldanas, eram aproximadas lenta e continuamente. 
Tanto sofreram os índios na peia e no "tronco" que, embora o Código Penal capitule como crime a prisão em cárcere privado, deve-se saudar a adoção desse delito como um inegável progresso no exercício da "proteção ao índio".

Sem ironia pode-se afirmar que os castigos de trabalho forçado e de prisão em cárcere privado representavam a humanização das relações índio-SPI.

Isso porque, de maneira geral, não se respeitava o indígena como pessoa humana, servindo homens e mulheres, como animais de carga, cujo trabalho deve reverter ao funcionário (MINISTÉRIO DO INTERIOR, proc. no $4.483 / 68$, v. 20,p. 4.913 apud GUIMARÃES, 2015, p.62-3)

Além de torturas, outras formas de violência foram levantadas. De acordo com o procurador, sobre o uso do trabalho e da usurpação dos produtos:

O trabalho escravo não era a única forma de exploração. Muito adotada também era a usurpação do produto do trabalho. Os roçados laboriosamente cultivados, eram sumariamente arrebatados do miserável sem pagamento de indenização ou satisfação prestada (MINISTÉRIO DO INTERIOR, proc. no 4.483/68, v. 20,p. 4.913 apud GUIMARÃES, 2015, p.62-3).

A desassistência era recorrente, favorecendo as doenças e a miséria entre os grupos indígenas sobre a tutela do SPI:

A Comissão viu cenas de fome, de miséria, de subnutrição, de peste, de parasitose externa e interna, quadros esses de revoltar o indivíduo mais insensível.

Não têm seus membros a veleidade de conhecer as mazelas do SPI. O pouco que lhes foi dado ver é suficiente para causar espanto e horror (MINISTÉRIO DO INTERIOR, proc. no 4.483/68, v. 20,p. 4.917 apud GUIMARÃES, 2015, p.63-4).

No mesmo posto indígena onde era recorrente a prática da tortura, a comissão presenciou o estado de descaso com a saúde dos indígenas:

Em Guarita (IR7-RGS), por exemplo, seguindo uma família que se escondia, fomos encontrar duas criancinhas sob uma moita tendo as cabecinhas quase 
completamente apodrecidas de horrorosos tumores provocados pelo berne, parasita bovino.

[...]

Encontramos a "enfermaria" - antro abjeto e sórdido ocupado conjuntamente por cães, porcos e uma doente, no mesmo quarto infecto. $O$ instrumental estava completamente deteriorado, apesar de o Chefe haver contratado sua própria esposa para "supervisionar" o antro (MINISTÉRIO DO INTERIOR, proc. no $4.483 / 68$, v. 20, p. 4.917 apud GUIMARÃES, 2015, p.64).

Jáder Figueiredo também menciona casos de assassinatos que viriam a ser relatados em notícias e matérias do JB no ano de investigação da comissão. Nas suas palavras,

o Serviço de Proteção aos índios degenerou a ponto de persegui-los até ao extermínio. Relembram-se aqui os vários massacres, muitos dos quais denunciados como escândalo sem, todavia, merecer maior interesse das autoridades.

Citaremos, entre outros as chacinas do Maranhão, onde fazendeiros liquidaram toda uma nação, sem que o SPI opusesse qualquer reação. Anos depois o Departamento Federal de Segurança Pública tomou a iniciativa de instaurar inquérito, em vista da completa omissão do SPI.

O episódio da extinção da tribo localizada em Itabuna, na Bahia, a serem verdadeiras as acusações, é gravíssimo. Jamais foram apuradas as denúncias de que foi inoculado o vírus da varíola nos infelizes indígenas para que se pudessem distribuir suas terras entre figurões do Governo.

Mais recentemente os Cintas-Largas, em Mato Grosso, teriam sido exterminados à dinamite atirada de avião, e à extricnina, adicionada ao açúcar enquanto os mateiros os caçam, à tiros de "pi-ri-pi-pi" (metralhadora) e racham vivos, à facão, do púbis para a cabeça, o sobrevivente!!! Os criminosos continuam impunes, tanto que o Presidente desta Comissão viu um dos asseclas deste hediondo crime sossegadamente vendendo picolé às crianças em uma esquina de Cuiabá, sem que a justiça Matogrossense o incomode (MINISTÉRIO DO INTERIOR, proc. no 4.483/68, v. 20, p. 4.916-7 apud GUIMARÃES, 2015, p.63).

É importante destacar que a Comissão de Inquérito de 1967 insere-se no modelo retórico anticorrupção do grupo articulador do 
golpe de 31 de março de 1964, sobretudo da chamada "linha dura", da qual fazia parte tanto o ditador presidente, gal. Costa e Silva, quanto o ministro Albuquerque Lima. Um dos mecanismos de materialização dessa retórica, utilizado logo no primeiro ano de ditadura, foi o Inquérito Policia Militar, que antes de ser usado no combate à corrupção, era instrumentalizado como forma de repressão e demissão da oposição de qualquer um que fosse considerado subversivo nos departamentos públicos e no parlamento (ALVES, 1984). É possível dizer que os inquéritos administrativos também seguiam essa lógica, e que os interesses por trás da sua criação podem ser mais complexos que as preocupações humanitárias com os povos indígenas.

As motivações para a criação da Comissão de Inquérito e a divulgação das investigações pelo Ministro do Interior, Albuquerque Lima, não são claras. No entanto, o antropólogo estadunidense Shelton Davis (1978) apontou que a importância que o ministro começava a assumir dentro da cúpula militar e na política indigenista daquele momento pode ter sido um fator motivador. Já o cientista político Egon Heck(1996) defende que o interesse estava na capitulação da política indigenista para os planos desenvolvimentistas do governo, através da subordinação da nova instituição indigenista que seria criada, a Funai, ao também recém-criado Ministério do Interior. Além das hipóteses desses pesquisadores, acreditamos que as pressões internas e externas da imprensa nacional e internacional para que fossem investigados crimes contra os indígenas e o envolvimento de funcionários do Estado nessas violações de direitos territoriais e humanos, possivelmente tenham contribuído para o seguimento das investigações, já que eram antigas e numerosas as publicações que vinham tratando o assunto.

Através da leitura da bibliografia, e de jornais da época, é possível perceber que não era a intenção do Ministério do Interior vincular os crimes contra os indígenas e a suposta corrupção do SPI à ditadura militar. Como apresenta Elena Guimarães:

Fica claro que o objetivo do Inquérito Administrativo não é que a denúncia de crimes seja associada aos agentes do estado que estavam vinculados ao grupo político do golpe de 1964. Através do Inquérito, o Ministério quer provar que os crimes foram cometidos por funcionários corruptos, fruto da leniência do estado 
nos anos pré-golpe militar. E mais adiante corrobora o projeto de extinção do SPI e criação da Fundação Nacional do Índio, como se esta ideia fosse algo gestado pelos militares como solução e redenção para os problemas dos índios (2015, p.57-58).

No entanto, ainda que não fosse do interesse do governo, os fatos tornados públicos pelo Ministro do Interior e pelo procurador Jáder Figueiredo mobilizaram as imprensas internacional e brasileira, que cobraram resoluções, inclusive chegando a chamar de genocídio e "escândalo do século" a violência que ocorria no Brasil contra os povos indígenas (GUIMARÃES, 2015). Frente à exposição do governo aos casos de corrupção e de violações dos direitos humanos, Costa e Silva decidiu por extinguir o Serviço de Proteção aos Índios e criar uma nova instituição indigenista que pudesse desassociar a imagem da ditadura aos crimes veiculados pela imprensa. Em 1967 através do Decreto $\mathrm{n}^{\circ}$ 5.371 era criada a Fundação Nacional do Índio (Funai).

De acordo com o antropólogo José Mauro Gagliardi:

As informações sobre genocídio de índios atraíram a atenção da imprensa internacional e motivaram uma situação incômoda para o governo militar brasileiro. Para se livrar da situação delicada em que ficou, em razão das denúncias, e visando atender a pressões de interesses econômicos, o governo simplesmente extinguiu o Serviço de Proteção aos Índios (1989, p.284).

Com a extinção do SPI e a criação da Funai, como bem observou a Comissão Nacional da Verdade e pesquisadores sobre a temática, as violações dos direitos humanos e territoriais dos povos indígenas não cessaram de ser desrespeitados. O Relatório Figueiredo nos permite identificar, já nos primeiros anos de ditadura militar, entre muitos pontos, a recorrência de invasão das terras indígenas, a perspectiva assimilacionista e autoritária da política indigenista, a desassistência e o aparelhamento da instituição indigenista por grupos econômicos, práticas que tornam-se recorrentes e se intensificarão nas décadas de 1970 e 80 com a Funai, nos governos Médici, Geisel e Figueiredo. Os textos da imprensa da época também nos auxiliam a compreender a complexidade da relação entre política indigenista e interesses 
econômicos. Nesse sentido, os discursos do JB são fontes profícuas às pesquisas sobre essas relações e as violações dos direitos indígenas, assim como da sua inserção no Relatório Figueiredo.

\section{JB: flerte e crítica à ditadura}

O Jornal do Brasil foi criado no ano de 1891. Nasceu inicialmente monarquista, mas ao longo das décadas consolidou uma identidade republicana, católica e liberal, que se manteve apesar das inúmeras vezes que foi vendido (GOMES, 2006).

Durante a Primeira República, o JB foi o primeiro jornal a se inserir de forma bem-sucedida na matriz capitalista de produção, adotando uma modernização no maquinário, produzindo em larga escala a partir das rendas provenientes de propagandas que ocupavam a primeira página do jornal. Pela grande importância dada às propagandas e às matérias que fugiam do modelo literário de muitos jornais, o JB focava na publicização de notícias e anúncios mais populares, como jornal investigativo, no qual crimes tinham grande destaque, assim como aspectos da vida cotidiana das classes mais populares (GOMES, 2006). Seguiu esse modelo do "popularíssimo" por algumas décadas, até que durante a década de 1950, após perder espaço para outros jornais e ser vendido para a família da condessa Pereira Carneiro, passou por uma série de mudanças estruturais visando conquistar as elites (CHAMMAS, 2012).Em termos de posicionamento político, o JB desde sua criação negou-se à imparcialidade (GOMES, 2006), apoiando ou se opondo a governos, prática que se tornou mais aguda nos anos de crise do governo João Goulart - quando apoiou o golpe de 64 (CHAMMAS, 2012).

Durante os meses que antecederam a deposição de Goulart, o JB, em seus editoriais, expressava toda a sua oposição às reformas de base, que eram vistas pelo jornal como "radicais" e um perigo à democracia e à propriedade privada. Não apenas participou da desestabilização do governo Jango, como usou da retórica da "resistência democrática" e "defesa do regime", conclamando o exército e, por vezes, atores 
indeterminados a interferirem, apoiando assim o golpe civil-militar (CHAMMAS, 2012).

De tradição liberal, o JB apresentava características marcantes de parte da direita brasileira daquele período, para a qual saídas autoritárias eram toleradas desde que garantissem direitos individuais e o direito à propriedade. De acordo com Eduardo Chammas,

em um momento de crise, os liberais aceitavam de bom grado uma saída autoritária que recolocasse a democracia, garantindo os direitos individuais e a segurança da propriedade sem necessariamente manter os direitos sociais, já que - na lógica liberal eles limitam a propriedade e os direitos individuais. Foi nessa experiência que muitos liberais se inspiraram quando conspiraram pelo golpe de 1964, acreditando que, assim como em 1945, excluído o trabalhismo da cena política em seguida seriam convocadas novas eleições (2012, p.44).

O padrão de relacionamento entre o JB e os governos da ditadura era dúbio, oscilando entre o apoio e a crítica velada, dependendo da conjuntura (CHAMMAS, 2012). Essa também foi uma característica da produção discursiva a respeito dos povos indígenas nas reportagens, editoriais e notícias, quando a política indigenista do governo ora era criticada, ora tinha seus feitos exaltados, entre os anos de 1965 e 1968. Destacamos que as condições de produção de textos da imprensa, no recorte temporal da Comissão de Inquérito do Ministério do Interior e de divulgação do Relatório Figueiredo, encontrava-se no contexto mais geral de institucionalização da ditadura e do modelo repressivo, através, por exemplo, da adoção de leis e atos de caráter autoritário como a Lei de Imprensa de 1967, que regulava a liberdade de pensamento, de informação e permitia a censura (SOARES, 1989; FICO, 2003), e o Al-5 a partir de dezembro de 1968. As possibilidades de cerceamento da liberdade de expressão eram muitas.

Não apenas os interesses internos ao jornal poderiam influenciar na forma como o mesmo, através de suas matérias, noticias e editoriais, se posicionava em relação à ditadura e suas ações. Durante a ditadura, mesmo nos seus primeiros anos, antes da consolidação com o Al-5, os órgãos de imprensa estavam sujeitos a diversas formas de censura, intervenções e violência: pressões econômicas, através da perda de 
publicidade estatal, empastelamentos, retirada de edições de circulação, prisões de jornalistas e proprietários (FICO, 2003; KUSHNIR, 2004; SOARES, 1989). Apesar disso, na década de 1960 uma série de denúncias foi feita pelos jornais brasileiros a respeito de violações dos direitos indígenas cometidas por agentes estatais e civis. Não foram poucas as matérias, editoriais e notícias que relatavam crimes contra os indígenas e a espoliação de suas terras e patrimônios na imprensa nacional e internacional. Nesse campo de denúncias, o JB teve seu papel.

\section{As violações dos direitos indígenas no JB antes da Comissão de Inquérito de 1967}

No contexto das investigações da Comissão de Inquérito do Ministério do Interior de 1967, e de crise do SPI,o JB apresentou diversas matérias sobre a situação dos indígenas no Brasil, que na sua maioria assumiam tom de denúncia. É possível observar na produção jornalística daquele ano que muitas reportagens e editoriais traziam referências a declarações do procurador chefe da comissão, Jáder Figueiredo, ou do ministro do Interior, gal. Albuquerque Lima, sobre irregularidades e crimes cometidos contra os indígenas por funcionários do SPI ou com a sua conivência.

Não obstante, essas denúncias não foram específicas apenas dos anos de investigação e divulgação da Comissão de Inquérito. Nas pesquisas no acervo do Jornal do Brasil na Hemeroteca Digital da Biblioteca Nacional, nos registros dos anos de 1965 a 1968, identificamos dezenas de textos antes da criação da Comissão de Inquérito do Ministério do Interior que abordavam a corrupção presente no SPI e a questão da violação dos direitos indígenas, embora os crimes contra os indígenas e o impedimento do exercício dos seus direitos territoriais muitas das vezes não fossem identificados nesses termos.

Nas notícias do ano 1965, que abordavam os crimes cometidos contra os indígenas e a invasão de suas terras, os agentes dessa violência eram, geralmente, apresentados como civis - seringueiros, madeireiros, garimpeiros e fazendeiros. Um exemplo é a notícia de 26 de março de 1965, "Doenças e tiros matam um índio por dia no Mato 
Grosso", que trazia as denúncias de um padre da Missão Anchieta de Uriati, no Mato Grosso, chamado pe. Weber, o qual prestava assistência a indígenas na região e tentava "civilizá-los". De acordo com Weber, um indígena morria por dia no Mato Grosso de fome, doenças e tiros de compradores de terras e seringueiros invasores. O padre ainda reclamava da falta de ajuda financeira e pedia a doação de paliativos para dar seguimento à assistência dos "índios".

Ainda localizamos para o ano de 1965 matérias que compuseram uma série chamada "Rondon, 75 anos depois", um conjunto de seis reportagens de título "No caminho dos semivivos" publicadas em junho, que possuíam um certo saudosismo à política indigenista de Rondon e destacava como que o SPI havia se tornado um órgão ineficiente para oferecer proteção aos indígenas. A série de reportagens resultou de visitas que a equipe de reportagem do JB realizou com o inspetor da $6^{\circ}$ inspetoria do Mato Grosso, Hélio Bucker, a diversos postos indígenas do Mato Grosso, sobretudo em território dos Bororo. Assinadas por Juvenal Portela, as reportagens partiam das reclamações feitas pelo inspetor sobre a falta de verbas, despreparo de funcionários, falta de autonomia dos postos indígenas e de segurança dos servidores frente às invasões às terras indígenas. Também destacavam a participação de funcionários do SPI em maus tratos aos indígenas e a desassistência, que levavam a situações de doenças, além da participação de alguns em irregularidades administrativas nos postos indígenas - aspectos das representações sobre o SPI que viriam a se tornar mais recorrentes a partir das investigações de 1967.

A base da argumentação do jornal a respeito da desassistência aos povos indígenas era a defesa de que os decretos do SPI, que estabeleciam que o órgão deveria prestar assistência, proteção e "civilizar" os indígenas, estariam sendo descumpridos. Entretanto, apesar das denúncias levantadas sobre a falta de verbas, de invasões de terras indígenas a partir da titulação irregular promovida pelo governo do Mato Grosso, da inabilidade e despreparo dos funcionários do SPI, da conivência de servidores com os interesses de fazendeiros, da falta de cuidado e tratamento de saúde dos indígenas, entre outros aspectos, algumas reportagens da série apresentavam uma visão preconceituosa e estereotipada, por vezes, racista, em relação ao indígena. 
O próprio título das matérias se referindo aos indígenas como "semivivos", embora de caráter denunciativo, é representativo da visão estereotipada sobre o nativo espoliado. Os indígenas da $6^{a}$ inspetoria eram representados como "primitivos" e também como "preguiçosos", sempre numa relação dicotômica com o chamado "civilizado". Na representação que se construía sobre os indígenas, estes apareciam como uma categoria transitória num processo de evolução. No discurso há um certo pesar sobre a política indigenista em falência, que deveria "integrar" o indígena à "civilização".

$\mathrm{Na}$ fala do jornalista, que teria presenciado difíceis condições de sobrevivência dos indígenas do posto Lima Simões, onde viviam Xavante e Bakairi, na $6^{\circ}$ inspetoria do SPI, no Mato Grosso:

Os índios não reclamam contra um estado de coisas que lhes dá uma condição de raça inferior. Essa condição se percebe em muitos fatores, dos quais me parecem os mais importantes: 1. Doentes vivem misturados aos sadios; 2 . O interior das casas é antihigiênico; 3.As mulheres não têm qualquer proteção no instante do parto, nem antes ou depois; 4 . As crianças nascem e crescem sem a menor assistência 5. Falta trabalho e com isso muitos índios, entregues ao lazer, tornam-se imprestáveis, em alguns casos. E tudo isso se deve ao abandono a que foram entregues pela omissão do SPI (Jornal do Brasil, 13 de junho de 1965, Cad.B, p.8. tít.: No caminho dos semivivos).

$\mathrm{Na}$ passagem acima fica claro um dos elementos que levariam esses "índios" à "civilização": o trabalho. Apresenta-se a visão do índio indolente, cujo desinteresse no trabalho produtivista capitalista seria uma das principais razões para seu "atraso". Ademais, o indígena é representado como um ser passivo, incapaz de resistir à condição imposta de "raça inferior", um "semivivo" diante da violência que sofriam. A tutela e a "civilização" seriam assim a única forma de sua humanização.

Também em outra matéria do dossiê podemos observar a perspectiva assimilacionista e tutelar em relação aos indígenas:

Já não se trata de tirar o índio da miséria em que vive. Isto é urgente, mas também é urgente lhe dar uma condição humana e social tão digna como a de qualquer 
civilizado. Integra-lo na vida comum, dar-lhe o mesmo direito de cidadão civilizado, ajudar-Ihe a ter uma consciência de seus problemas são medidas que não podem ficar para depois. Não se pode desconhecer que ainda é grande o numero de indígenas não cativados e é com esses que se devem preocupar os responsáveis pelo assunto, oferecendo meios aos já pacificados, a fim de que eles possam ajudar a salvar os outros (Jornal do Brasil, 15 de junho de 1965, Cad.B, p.8, tít.: No caminho dos semivivos).

As reportagens do conjunto de matérias "No caminho dos semivivos", antes de 1967, foi a mais ampla do JB sobre o SPI e a situação dos povos indígenas no país. Além dessas reportagens, ainda que de volume menor do que teriam a partir de 1967, no ano de 1966 também foram publicadas denúncias sobre situações que em pouco tempo estariam na conclusão do Relatório Figueiredo, como notícias sobre o envolvimento de funcionários do SPI em esquemas de corrupção, torturas, abusos e roubos de patrimônio indígena.

No ano de 1966, que precedeu a criação da Comissão de Inquérito do Ministério do Interior, há notícias e matérias publicadas entre janeiro e maio que traziam o posicionamento do próprio SPI sobre a situação dos indígenas e as pressões de grupos econômicos, como nas notícias "Conflitos acabarão quando branco não se meter com o índio, diz o diretor do SPI" e "Diretor do SPI culpa Banco da Amazônia por massacres dos índios em Mato Grosso". Outras tratavam da violência promovida por civis contra os indígenas, como eram as notícias "Polícia Federal mobilizada para prevenir chacina de indígenas no Maranhão" e "Posseiros ameaçam índios", mas eram mais frequentes as que versavam sobre supostas participações de funcionários do SPI em desvio de verbas, esbulho de terras e de patrimônio dos postos indígenas, e crimes cometidos contra a vida dos indígenas.

Um desses textos é a notícia de onze de dezembro de 1966 "Servidores do SPI acusados de crimes contra índios e prostituição de menores", na qual eram apresentadas informações sobre um radiograma que o chefe do setor de Assistência aos Índios, Nilo Veloso, teria endereçado ao diretor do SPI, cel. Hamilton de Oliveira, fazendo acusações a servidores do órgão. O radiograma, que segundo o jornal seria peça fundamental num inquérito aberto pelo Ministério da 
Agricultura6, falava sobre abusos sofridos pelos indígenas da llha de Bananal cometidos por um funcionário do posto indígena - entre eles o de prostituição de meninas menores de 18 anos. O funcionário, que supostamente seria próximo ao próprio diretor do SPI, havia sido designado para apurar as irregularidades como a venda de gados, e teria acabado por se relacionar e prostituir indígenas da região. O JB ainda reproduziu o radiograma de Nilo Veloso: "Alerto V.S contra ondas de crimes que vêm tendo como autores não mais garimpeiros, seringueiros ou fazendeiros, mas sim servidores do SPI, que envergonham e desonram os cargos que exercem" (Jornal do Brasil, 1 dez.1966, $1{ }^{\text {a }}$ Caderno, tít."Servidores do SPI acusados de crimes contra índios e prostituição de menores").

Outra notícia de seis de dezembro de 1966, de título "Polícia apura por que SPI arrendou cassiterita dos índios a firma particular", trazia informações recentes sobre uma investigação da Polícia Federal para averiguar o arrendamento feito pelo SPI a uma empresa particular para exploração de cassiterita no território dos Pakaa-Nova, em Rondônia, cuja renda revertida aos indígenas seria de apenas $10 \%$. Esse é um caso da chamada "renda indígena", amplamente utilizada para custear o funcionamento dos postos indígenas nos anos de redução do orçamento do SPI. Não podemos afirmar se nesse acontecimento apresentado pela imprensa houve de fato corrupção, mas é possível dizer que a renda indígena favoreceu os esbulhos sobre as terras e patrimônio indígena por funcionários do SPI e civis, além da apropriação dessa renda, resultado da venda de produtos produzidos por indígenas e do arrendamento de terras e exploração do solo (HECK,1996; GUIMARÃES, 2015).

A exploração das terras indígenas pelo SPI, em forma de arrendamento da terra, de recursos naturais ou do patrimônio indígena, não foi uma prática específica do período ditatorial. No entanto, essa foi a perspectiva seguida pelos governos ditatoriais, presente, sobretudo, nos discursos dos diretores e presidentes dos órgãos indigenistas, cuja adequação aos projetos de desenvolvimento favoreceu o aumento de invasões de terras indígenas e a violência contra esses povos, além dos casos de corrupção, como mencionado (DAVIS, 1978; HECK, 1996). É

\footnotetext{
${ }^{6}$ A Comissão de Inquérito do Ministério da Agricultura criada em 1966 foi dissolvida no mesmo ano.
} 
esse quadro - que não começa na ditadura, mas nela se intensifica que o JB narrou antes da Comissão de Inquérito de 1967 do Ministério do Interior, e seguiu cobrindo durante a realização da mesma. Os relatos nada mais eram do que práticas recorrentes na realização da política indigenista da ditadura militar.

\section{A cobertura das investigações da Comissão de Inquérito de 1967 do Ministério do Interior, e do resultante Relatório Figueiredo}

Nos anos de 1967 e 1968 o JB cobriu não apenas as investigações da Comissão de Inquérito presidida por Jáder Figueiredo, mas sua repercussão entre a imprensa internacional. Também cobrou do Ministério do Interior e do governo ditatorial a punição dos funcionários que teriam cometido crimes contra os indígenas e se envolvido em esquemas de corrupção no SPI.

As publicações de 1967 e 1968 foram principalmente baseadas nas investigações da Comissão de Inquérito do Ministério do Interior e no seu texto final, o Relatório Figueiredo. Assim, o JB centrou seus esforços em divulgar ocorrências de irregularidades e crimes contra os indígenas envolvendo funcionários do SPI - e quando apresentados outros personagens civis nas violações, eram os funcionários do órgão que tinham maior destaque. As notícias e reportagens relatavam como indígenas por todo o país estavam submetidos a situações de violência, que envolviam desde torturas e prostituição de mulheres indígenas ao extermínio de tribos inteiras, por agência ou conivência do órgão; o SPI havia se tornado o principal algoz dos povos indígenas brasileiros nos discursos do JB. Tal aspecto estava presente nos próprios títulos das notícias, como na publicação de cinco de novembro de 1967 "Comissão que Albuquerque nomeou já sabe mal que SPI causa a índios do Paraná", que trazia os primeiros resultados da investigação da Comissão de Inquérito.

Na notícia, era relatado que Jáder Figueiredo e sua equipe já tinham conhecimento sobre a participação de grandes grupos econômicos, funcionários do SPI, autoridades estaduais e parlamentares na extração de madeira e invasão de terras indígenas no Paraná. Além 
disso, eram apontadas algumas outras denúncias que seriam levadas pelo mesmo procurador à polícia após a conclusão das investigações do Ministério do Interior. Por exemplo, o deslocamento compulsório de uma aldeia dos Xavante no Mato Grosso em 1966, que teria levado à morte de 50 deles, a invasão e venda de terras dos Bororo, Xavante e Memkromopires ${ }^{7}$, no Mato Grosso e o massacre dos Canela e dos CintaLarga em Rondônia - esse último resultando em vários mortos e uma indígena retalhada ao meio 8 .

Algumas matérias ofereciam uma narrativa mais panorâmica sobre a situação indígena no país. Por exemplo, na reportagem "Todos os meios foram lícitos para liquidar índios"9, de cinco de maio de 1968, é possível observar a amplitude em termos territoriais, modalidades das violações e irregularidades, além de suas características. A apresentação da conjuntura da política indigenista e da violência contra os indígenas era baseada nos relatos de situações presenciadas por Jáder Figueiredo e da documentação de investigações de anos anteriores recuperada pela Comissão de Inquérito. Além de um panorama demográfico sobre os povos indígenas nos vinte anos anteriores, alguns dos fatos levantados na reportagem foram: o massacre dos Cinta-Larga por pistoleiros a mando de um seringalista do estado do Mato Grosso em 1963; o envenenamento dos Beiço-de-Pau (Tapayuna) por açúcar contaminado com arsênico e formicida doado por seringalistas também em Mato Grosso; o assassinato de indígenas da etnia Timbira no Maranhão; a escravização de centenas de Ticuna por fazendeiros no Alto Solimões; a venda ilegal de madeiras por funcionária do SPI nas terras dos Guarani e Kaingang;e a recorrência da prática de tortura nos postos indígenas.

A reportagem ainda trazia depoimentos do ministro Albuquerque Lima e do procurador Jáder Figueiredo que mostravam indignação sobre a violência contra os indígenas e o estado moral no qual encontrava-se o SPI. Na fala de Albuquerque Lima, as investigações da comissão haviam descoberto "do roubo ao estupro, da grilagem ao assassinato,

\footnotetext{
${ }^{7}$ Apesar deste nome ter sido arrolado na documentação, não encontrei nenhuma referência ou outro registro sobre a existência desta etnia.

8 De acordo com Elena Guimarães em sua dissertação de mestrado, o caso do massacre dos CintaLargaocorreu no ano de 1963 e foi arrolado na Comissão de Inquérito daquele ano a partir de Relatório do CNPI ao Ministério da Agricultura.

${ }^{9} \mathrm{~A}$ matéria foi assinada pelo Departamento de Pesquisa do $J B$.
} 
do suborno às torturas medievais, passando pelo lenocínio, pelos desregramentos e taras sexuais". Já Figueiredo afirmava que estava ocorrendo um genocídio contra os indígenas, e assim como o ministro do Interior, em nenhum momento responsabilizava o governo ditatorial sobre o modelo de política indigenista que era praticado:

O genocídio vem sendo praticado impunemente. Os espancamentos, independentes de idade e sexo, são praticados como rotina e só despertam atenção quando aplicados em exagero, provocam a morte (Jornal do Brasil, 5 maio $1968,1^{\circ}$ Caderno, p.28, tít.:Todos os meios foram lícitos para liquidar índios).

Era prática recorrente - tanto nos discursos do Ministro do Interior e de Jáder Figueiredo, como nos do JB - responsabilizar os funcionários do SPI pelos crimes cometidos, sem mencionar as condições políticas e econômicas para tal. Não era mencionado o fato de a política indigenista daquele contexto ser tocada sob um regime autoritário e uma política econômica desenvolvimentista, que refletia em pressões sobre as terras indígenas.

A cultura política (BRESTEIN, 1998) do JB correspondia a uma cultura política das classes médias e elites do Brasil, influenciada principalmente pelo liberalismo e pela defesa dos direitos individuais (CHAMMAS, 2012). Além disso, as representações sobre os indígenas muitas vezes compartilhavam das ideias hegemônicas, para as quais os indígenas eram (e ainda hoje são, por parte da sociedade civil brasileira) vistos como tutelados, atrasados, fadados ao desaparecimento, portanto, sujeitos passivos dos processos históricos. Esses elementos presentes nos discursos do JB eram mais frequentemente abordados nos editorais políticos, embora também estivessem presentes em reportagens, como na mencionada série de 1965, "No caminho dos semivivos".

Nos editoriais políticos, as opiniões e críticas do jornal eram expostas com maior clareza, onde o papel de ator político do JB era mais explícito na construção discursiva sobre as pautas da semana, assim como a forma que enxergavam os povos indígenas e sua posição sobre as violações. Por muitas edições, em 1967 e 1968, a querela do SPI e a questão das investigações do Ministério do Interior sobre os 
crimes cometidos contra os indígenas foram temas de editoriais inflamados do jornal. Na época, os editoriais estavam sob a responsabilidade do editor chefe Alberto Dines ${ }^{10}$, conhecido por sua defesa do papel de agente crítico do jornalista. No contexto das investigações e declarações do procurador Jáder Figueiredo, avolumaram-se editoriais exaltados em que se cobrava ao governo federal a punição dos culpados nos crimes contra os indígenas e o bem público.

Ainda em 1967, durante as investigações, no editorial "Corrupção na selva", com tom de indignação, é emitida a opinião do jornal a respeito da situação do SPI e dos indígenas. O texto critica o SPI, que, no lugar de proteger os indígenas e seu patrimônio, havia chegado ao ponto de cometer crimes contra aqueles. Também saúda a atitude do governo na abertura do inquérito e afirma que a corrupção no SPI era um "tumor maligno" que afastava os indígenas de suas terras para favorecer os interesses de seringalistas e madeireiros, apesar da resistência. $O$ que é mais interessante neste editorial, além de destacar que o cerne da questão era a disputa pela terra (apesar de não falar explicitamente sobre violação de direitos indígenas), é o destaque para a infração de leis: "Do furto simples ao homicídio, do roubo ao estupro, do peculato ao estelionato, os protetores dos índios escalaram desgraçadamente todos os artigos do Código, violando leis escritas e leis não escritas" (Jornal do Brasil, 26 out. 1968, $1^{\circ}$ Caderno, p.6, tít.:Corrupção na Selva).

Nos editoriais de 1968, na conjuntura de expectativas para a conclusão do inquérito e a punição dos identificados como criminosos, as pressões sobre o Ministério do Interior e o governo aumentaram. 0 editorial "Bárbaros contra índios", de dezoito de março de 1968, cobrava do governo a punição dos culpados pelos crimes contra os indígenas e pela corrupção do SPI. Na crítica do editorial, o apelo para a situação do indígena é categórico, pois

é justamente o fato de o índio não votar, de ser tutelado da Nação, que o torna mais precioso. É um

\footnotetext{
10 Alberto Dines foi um dos jornalistas de maior prestígio no país, escritor de vários livros de comunicação com foco no papel crítico do jornalista. Na época, Dines era o editor chefe do JB. O diretor presidente era C. Pereira Carneiro (na verdade Condessa Pereira Carneiro) e o diretor M. F. de Nascimento Brito (Manuel Francisco de Nascimento Brito).
} 
dependente, uma criança. E um Congresso, um país em geral que não cuida dos seus filhos indefesos dificilmente terá maturidade para resolver outros problemas (Jornal do Brasil, 18 mar. 1968, 10 Caderno, p.6, tít.: Bárbaros contra índios).

Além da representação dos indígenas como crianças, corriqueiramente uma ideia fatalista sobre eles era vinculada, pois se afirmava que um extermínio estava em curso. No editorial " $O$ nome do Brasil", de 26 de março de 1968,o jornal cobrava a responsabilidade do governo na situação que se apresentava, e destacava a preocupação da opinião pública internacional expressa em diferentes jornais, entre eles o New York Times, mencionando a dimensão de "escândalo" que as notícias sobre genocídio de indígenas brasileiros haviam tomado no exterior. Na cobrança pela punição dos "criminosos", "assassinos" de "índios", o editorial comparava:

Os nazistas, quando mantinham seus campos de concentração mantinham igualmente silêncio a respeito deles. Só quando ocorreu a derrota do terceiro reich é que o mundo comprovou o que se conhecia a respeito do silencio governamental: aqueles montes de cadáveres, aqueles fornos crematórios, a sinistra historia de um regime de arrogantes canalhas. [...] Silêncio num caso de tal gravidade tem o nome de cumplicidade (Jornal do Brasil, 26 mar. 1968, 10 Caderno, p.6, tít.: O Nome do Brasil).

Na perspectiva fatalista sobre as condições de sobrevivência dos povos indígenas, havia também uma preocupação do JB com a imagem do país. No editorial "Genocídio Arquivado", de 28 de março de 1968, foram feitas duras críticas ao ministro do Interior, gal. Albuquerque Lima, pela morosidade em punir as pessoas identificadas na Comissão de Inquérito pelos crimes cometidos contra os indígenas e pela corrupção do SPI. Ademais, criticava o posicionamento do ministro que. após divulgar os casos de crimes contra os indígenas e que envolviam o SPI, havia dito que o assunto estaria sendo tratado com sensacionalismo pela imprensa brasileira e internacional. O JB ressaltava que a opinião pública e a imprensa internacional "horrorizavam-se" com o "genocídio" cometido no Brasil, e que o ministro, ao divulgar informações sobre as investigações, havia desencadeado uma tempestade que não sabia como 
deter. Por conseguinte, além das críticas ao governo, o editorial demonstra apreensão com o arquivamento do inquérito e a imagem do país no exterior:

Não é todos os dias que um governo admite o genocídio em suas fronteiras. Já dissemos e voltamos a dizê-lo: é inútil querer arquivar o inquérito do SPI, e a única maneira de nos provarmos um país civilizado é publicar o inquérito e punir os criminosos (Jornal do Brasil, 28 mar. 1968, 10Caderno, p.6, tít.: Genocídio Arquivado).

É importante ressaltar, como dito anteriormente, que a divulgação das investigações por parte do Ministério do Interior não tinha como objetivo ligar o regime aos supostos esquemas de corrupção e à situação de abandono e violência na qual estava submetida grande parte dos indígenas sob a tutela do SPI. Pelo contrário, o interesse era atribuir esses casos aos governos anteriores ao golpe de 1964. Na prática, a divulgação terminou por aumentar as pressões sobre o regime por parte da imprensa nacional e internacional, e de organizações estrangeiras, colocando o JB e o Ministério do Interior em rota de colisão. Como mencionado no editorial, Albuquerque Lima havia iniciado uma tempestade que não conseguia mais deter.

Podemos observar que, embora os editoriais e matérias do JB denunciassem as violências contra os povos indígenas, essas denúncias eram realizadas majoritariamente sobre representações estereotipadas que infantilizavam e silenciavam qualquer forma de agência e resistência indígena, assentadas num discurso fatalista sobre o destino deles. É preciso ver esses discursos como discursos políticos, como disputa por poder, que também reverberavam as ideias hegemônicas presentes na sociedade brasileira, sobretudo, branca e rica ou de classe média.

$O$ indígena infantilizado deveria ser salvo do processo de genocídio em curso do qual o jornal tanto falava em seus editoriais. No entanto, o impedimento desse processo se daria não apenas na garantia de seu território e segurança, ou punição daqueles que o violentava, mas através da sua progressiva assimilação ao mundo branco, chamado de "civilizado". As particularidades culturais, a autonomia nas formas de 
organização social e política desses povos. não eram consideradas nas reportagens e editoriais.

Em alguns editoriais em que o JB criticava diretamente a política indigenista e identificava a disputa por terras como o centro das violações dos direitos territoriais dos povos indígenas, a visão infantilizada do indígena era o que "legitimava" a necessidade das demarcações:

\begin{abstract}
Demarquem-se as terras - que todos imaginavam delimitada há muito - e tomem-se as providências para que não se repitam. Mas esses são gestos de quem entra numa casa em que as crianças foram chacinadas e chama o serralheiro para que as portas passem a ser realmente bem fechadas (Jornal do Brasil, 20 maio 1968, 10Caderno, p.6, tít.: Crianças chacinadas.)
\end{abstract}

Nasrepresentações de violadores e violados, o uso de adjetivações ao segundo grupo era muito mais frequente na construção discursiva dos editoriais. No editorial de primeiro de junho de 1968, de título "Crime compensador", os industriais madeireiros, seringueiros ou castanheiros, identificados como personagens invasores das terras indígenas, não tinham atribuídos aos seus nomes adjetivos negativos. Sobre os crimes e a relação com as disputas de terra:

Os crimes eram tão odiosos, e cometidos tão exclusivamente em troca de vantagens pecuniárias, que se aguardava para êles uma punição exemplar, que nos reconciliasse com a idéia que de nós fazemos, de um povo humano, e bom, e não de um bando de assassinos de selvagens, por cobiça de suas terras. [...] Industriais de madeira, de borracha ou de castanha que desalojam os índios das terras que a Constituição lhes garante, devem estar dizendo a si mesmos que 0 crime contra selvagens compensa. O prêmio é alto, são imensas extensões de terra. A punição é nula (Jornal do Brasil, 1 jun. 1968, $1^{\circ}$ Caderno, p.6, tít.: Crime compensador, grifo nosso).

A questão do direito aparece mais explicitamente num editorial de 26 de outubro de 1968. Esse editorial comenta a criação pela presidência de um Conselho de Defesa dos Direitos da Pessoa Humana, que teria a função de fazer valer o respeito dos direitos humanos em 
território brasileiro. Apesar disso, o JB ressalta que a criação de um conselho não seria suficiente para a proteção dos direitos humanos, e que apenas práticas do governo poderiam garantir seu cumprimento atentando para o fato de ser a impunidade corriqueira. Para além disso, relembra que havia setores da sociedade mais vulneráveis a violações de direitos, como os indígenas, ligando a questão das violações dos direitos indígenas às violações dos direitos humanos:

Num país das dimensões e da complexidade do Brasil há direitos que precisam ser respeitados longe das avenidas e das praças das grandes cidades, como os direitos dos índios, que são tutelados da Nação. Êsses fazem um apelo direto à consciência nacional, já que os crimes contra eles podem em geral ser cometidos com impunidade (Jornal do Brasil, 26 out. 1968, $1^{\circ}$ Caderno, p.6, tít.: Direitos Humanos).

O JB fazia valer sua tradição pela defesa das liberdades individuais, já expostas anteriormente, embora fossem recorrentes representações exotizadas dos povos indígenas. A defesa pela integridade deste povos, a crítica à falta de amparo do Estado à saúde e subsistência, e as reinvindicações pela punição de "assassinos de índios" contrastavam com um posicionamento evolucionista, assimilacionista, no geral pouco problematizado sobre as razões para as violações apresentadas, sobretudo no que consistia sua relação com a política desenvolvimentista do governo ditatorial e o modelo de política indigenista adotado.

Compreendemos que estamos falando de um contexto de regime de exceção. Existiam outras formas de cerceamento da liberdade de imprensa, embora ainda não tivesse sido decretado o $\mathrm{Al}-5$. A forma com que o jornal representava os indígenas era muito parecida com a ideologia com que a política indigenista da ditadura era conduzida através do SPI, e que deixou de legado para a Funai: uma perspectiva assimilacionista, defensora da ideia de "integração" do indígena à sociedade nacional, para que ele também se tornasse um "civilizado". Essa mesma perspectiva influenciou as políticas desenvolvimentistas dos governos militares sobre as terras indígenas e favoreceu a corrupção interna no SPI através da renda indígena, contribuindo para a sua bancarrota. Sem perceber, o JB ideologicamente, do ponto de vista 
da forma como a política indigenista deveria ser conduzida, se aproximava dos responsáveis pelas violações que frequentemente eram pauta do jornal.

De acordo Anne-Marie Smith (2000), a crítica social mais profunda geralmente é inexistente nos jornais da grande imprensa, por conta da pretensão de objetividade de seus textos e pelos interesses particulares dos membros que detêm o poder na hierarquia do jornal e de seu público leitor - nesse caso, as classes médias e elites. Sendo assim,

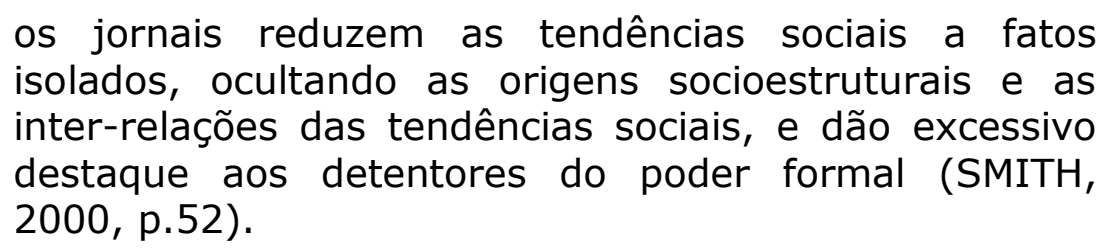

Essa passagem nos parece muito elucidativa a respeito de como as orientações internas e a linguagem da grande imprensa poderiam construir o discurso em relação à situação dos povos indígenas naqueles primeiros anos de ditadura. Normalmente, os crimes contra os indígenas ou mesmo as ocorrências de corrupção no SPI eram apresentados sem conexões com as condições socioestruturais, econômicas e políticas, que fomentavam esses processos, como as relações entre os crimes e o avanço de grandes empresas sobre territórios indígenas, a partir dos projetos de desenvolvimento do governo, ou a perspectiva assimilacionista que orientava os funcionários do Serviço. Frequentemente, nos editoriais, o governo ditatorial era responsabilizado a punir os culpados pelas violações, mas raramente era responsabilizado pela situação fundiária que levava a essas mesmas violações ou aos incentivos estatais à expansão de empresas agropecuárias e mineradoras que impactavam os povos indígenas.

É preciso levar em consideração que o relacionamento do JB com a ditadura era dúbio. Se muitas vezes as matérias e editoriais assumiam um tom de denúncia contra a política indigenista do governo, em outras, sobre o mesmo assunto, eram apresentados discursos convalescentes ou exaltadores de ações do governo. Alguns exemplos para essa relação dúbia são as notícias e matérias entre junho e julho de 1968, que apresentavam as promessas do Ministro do Interior, Albuquerque Lima, de devolução e demarcação de terras indígenas 
invadidas, "Albuquerque e Lima promete devolver aos índios todas as terras tomadas à força", "Govêrno prepara demarcação de terras dos índios para impedir a extinção da raça”, também notícias que exaltavam o poder tutelar de instituições do Estado como a Polícia Militar de Minas Gerais, que tornou-se responsável por postos indígenas onde vivia a tribo Maxakali, "PM mineira livra a tribo maxacali de extermínio por alcoolismo e grilagem".

\section{Considerações finais}

Nos anos de 1967 e 1968 o Jornal do Brasil e a imprensa cobriram as investigações da Comissão de Inquérito do Ministério do Interior de 1967 e o texto de inquérito, o Relatório Figueiredo, dando publicidade a fatos de violações dos direitos indígenas e de casos de corrupção dentro do Serviço de Proteção aos Índios, o SPI. Ocorrências de torturas, assassinatos, escravização, prostituição, venda e arrendamento de terras e patrimônio indígena, e apropriação indevida de verbas e rendas foram frequentes, aparecendo em dezenas de matérias, editoriais e notícias publicadas no período.

Além da diversidade de casos de crimes e violações relatados, dos depoimentos do ministro do Interior, Albuquerque Lima, e do procurador Jáder Figueiredo - de apresentar as expectativas para a divulgação do texto de inquérito e da punição dos criminosos, as críticas abertas ao governo e a repreensão do ministro sobre as pressões nacionais e internacionais - as publicações favorecem nossa compreensão sobre a proporção da violência contra os indígenas e a dimensão que o quadro havia tomado frente à opinião pública, gerando mal-estar no próprio Ministério do Interior que divulgara as investigações.

Embora os discursos do JB sobre a situação dos indígenas e do SPI fossem geralmente feitos sob tom denunciativo e o jornal criticasse abertamente o governo pela não punição dos responsáveis pelos crimes, as representações dos indígenas eram frequentemente fatalistas, exotizadas, evolucionistas, assimilacionistas, e, por vezes, racistas. A base argumentativa para as críticas nos editoriais e reportagens era a da 
necessidade da tutela sobre o indígena, visto como primitivo e infantil, que deveria ser protegido e "integrado" em algum momento à nação. 0 indígena era apresentado junto com seu par dicotômico, o "civilizado", e a razão para a preservação de seus direitos seria,principalmente, a sua condição de inferioridade em relação àquele.

Seguindo a linha da Comissão de Inquérito, o foco das publicações, a partir de 1967, cairia sobre os funcionários do SPI, embora a sua relação com grupos econômicos fosse muitas vezes mencionada, os funcionários do órgão eram representados como os principais algozes dos indígenas. Apesar de o fracasso da política indigenista do SPI ser destacado, nos textos não era questionada a perspectiva assimilacionista e desenvolvimentista que esse mesmo órgão assumiu na administração da ditadura. Críticas que relacionassem a situação dos indígenas com circunstâncias políticas e socioestruturais mais complexas eram praticamente ausentes, assim como sobre as condições da realização de uma política indigenista sob uma ditadura militar. Hipóteses para essas ausências podem ser muitas: o relacionamento ambíguo que o próprio jornal, e seus profissionais, dirigido pela condessa Pereira Carneiro, tinha com os primeiros dois governos da ditadura, a perspectiva ideológica que seguiam, as possibilidades de cerceamento da liberdade de expressão através da violência e de sanções econômicas da ditadura sobre os membros do jornal, ou todas elas juntas. Para verificar estas hipóteses, assim como para dimensionar a circularidade das informações apresentadas pelo jornal entre a população nacional, seria necessária uma investigação com corpo documental mais vasto e um recorte temporal mais amplo, o que não será possível no presente artigo. Seria interessante que outros trabalhos se debruçassem mais a fundo sobre estes possíveis elementos.

Relembramos que a cobertura do JB sobre a violência contra os indígenas não foi específica dos anos de investigação da Comissão de Inquérito do Ministério do Interior e da divulgação do Relatório Figueiredo. Nos anos anteriores, de 1965 e 1966, algumas notícias e reportagens que abordavam crimes contra indígenas e seu patrimônio, e a desassistência e inoperância do SPI foram publicadas. Embora muito pontuais, esses textos foram consolidando um padrão discursivo sobre 
o SPI e sobre os indígenas que se tornou recorrente no contexto de divulgação das investigações do Ministério do Interior e do relatório: a ideia de genocídio, da incapacidade do indígena e dos funcionários do SPI como principais responsáveis dos males infligidos aos povos indígenas no Brasil.

O Relatório Figueiredo e a divulgação dos fatos que o compunham se tornaram um grande cavalo de Tróia para o Ministério do Interior, que o havia divulgado, e para o governo. A saída imediata, além das acusações de sensacionalismo que Albuquerque Lima fazia à imprensa, foi a extinção do velho SPI e a criação da Funai, sob a retórica de renovação do indigenismo que protegeria e integraria lentamente o indígena à sociedade nacional. A nova instituição, durante a ditadura, acabou por seguir os mesmo erros do SPI, sobretudo em sua aparelhagem por grupos econômicos, nos anos de maior autoritarismo do regime. As violações dos direitos indígenas continuaram e se intensificaram com a Funai no período ditatorial, quando esteve à disposição dos interesses de latifundiários, da burguesia multinacional e dos governos.

Deslocamentos forçados, certidões falsas, construção de estradas e hidrelétricas sobre terras indígenas, subsídios para empresas multinacionais se estabelecerem em terras tradicionalmente ocupadas por povos indígenas, a criação da Guarda Rural Indígena (GRIN) e do Reformatório Agrícola Indígena Krenak foram práticas da ditadura em relação aos indígenas, articuladas aos interesses econômicos dos governos, da burguesia multinacional agrária e industrial. O relatório da Comissão Nacional da Verdade de 2014 foi o primeiro documento oficial a reconhecer a participação do Estado, sobretudo ditatorial, nas violações dos direitos indígenas e a destacar os aspectos citados. Para isso, a "redescoberta" do Relatório Figueiredo foi importantíssima, na medida em que possibilitou, a partir de um documento governamental, tornar público casos de violações dos direitos humanos dos povos indígenas - embora esquecidos pelo restante da sociedade nacional, jamais olvidados pelos próprios povos.

A análise dos jornais do período ditatorial, apesar de seus limites de produção, associados a documentos como o Relatório Figueiredo, permite que os pesquisadores aprofundem os estudos sobre as marcas 
que a ditadura militar deixou sobre a história dos indígenas brasileiros. Estudos que podem favorecer medidas de reparação histórica, tendo em vista que muitos dos impactos negativos do avanço das frentes econômicas e da política indigenista autoritária do período ainda não foram superados. Ademais, podem servir de instrumentos para os povos indígenas e para o movimento indígena nas reivindicações de demarcação e recuperação de suas terras tradicionais. Em tempos de negacionismo, da ascensão de movimentos e discursos contra os direitos e as populações indígenas, torna-se fundamental recontar a história da ditadura militar, recuperando o lugar onde estes povos foram colocados pelas narrativas da época e pela política indigenista. É neste sentido que o presente trabalho pretende contribuir. A CNV, ao trazer a público as violações dos direitos humanos dos povos indígenas, abriu a possibilidade de um terreno fértil e necessário para os historiadores, antropólogos e demais pesquisadores das ciências humanas debruçarem-se. Devemos fazê-lo.

Os limites de documentação que se tinha, ou pensava-se ter, para investigar essa história já estão praticamente superados com a divulgação de documentos sigilosos da ditadura e com a digitalização de centenas de jornais brasileiros disponibilizados online para consulta. Além disso, caso encontremos obstáculos para o acesso a essas fontes, ainda sim, teremos um tipo de documentação que continua resistindo a qualquer tipo de silenciamento: a memória dos povos indígenas que, a despeito de qualquer documento de papel, não se perde e não se perdeu durante os mais de 50 anos do golpe civil-militar de 1964 . Foi o exercício desta memória, quando indígenas reivindicaram um eixo de pesquisa para violações dos direitos humanos de seus povos na ditadura, que possibilitou à Comissão Nacional da Verdade iniciar as pesquisas e chegar ao "desaparecido" Relatório Figueiredo, abrindo precedente para novas pesquisas e busca de outros documentos. Deixemos a discussão sobre memória para outro momento.

Referências bibliográficas 
ALVES, Maria Helena Moreira. Estado e oposição no Brasil (1964-1984). Petrópolis: Vozes. 1984.

BARBOSA, Rodrigo Lins. O Estado e a questão indígena: crimes e corrupção no SPI e na Funai (1964-1969). 2016. 260 f. Tese (Mestrado em História) - Programa de PósGraduação em História, Universidade Federal de Pernambuco - UFPE. Recife: UFPE, [2016].

BERSTEIN, Serge. A cultura política. In: RIOUX, Jean-Pierre; SIRINELLI, JeanFrançois (Org.). Para uma história cultural. Lisboa: Editorial Estampa, 1998. p. 349364.

BRASIL. Decreto $\mathbf{n}^{\mathbf{0}}$ 8.072, de 20 de junho de 1910. Cria o Serviço de Proteção aos Índios e Localização de Trabalhadores Nacionais e aprova o respectivo regulamento. Disponível em: 〈http://www.planalto.gov.br/ccivil_03/decreto/1910-1929/D8072.htm>. Acesso em 20 out. 2017.

Decreto $n^{0}$ 5.484, de 27 de junho de 1928. Regula a situação dos índios nascidos no território nacional. Disponível em: <http://www2.camara.leg.br/legin/fed/decret/1920-1929/decreto-5484-27-junho-1928562434-publicacaooriginal-86456-pl.html>. Acesso em 20 out. 2017.

Decreto $\mathrm{n}^{\mathbf{0}} \mathbf{1 0 . 6 5 2}$, de 16 de outubro de 1942. Aprova o Regimento do Serviço de Proteção aos Índios, do Ministério da Agricultura. Disponível em: <http://www2.camara.leg.br/legin/fed/decret/1940-1949/decreto-10652-16-outubro1942-464627-publicacaooriginal-1-pe.html>. Acesso em 20 out. 2017.

Disponível

Constituição dos Estados Unidos do Brasil de 18 de setembro de 1946. <http://www.planalto.gov.br/ccivil_03/Constituicao/Constituicao46.htm>. Acesso em 20 out. 2017.

Constituição da República Federativa do Brasil de 1967. Disponível em: <http://www.planalto.gov.br/ccivil_03/Constituicao/Constituicao67.htm>. Acesso em 20 out. 2017.

Lei no 5.371, de 05 de dezembro de 1967. Autoriza a instituição da Fundação Nacional do Índio e dá outras providências. Disponível em: <http://www.planalto.gov.br/ccivil_03/leis/1950-1969/L5371.htm>. Acesso em 20 out. 2017.

Ato Institucional $\mathrm{n}^{\mathbf{0}} \mathbf{5}$, de 13 de dezembro de 1968. Disponível em: <http://www.planalto.gov.br/ccivil_03/AIT/ait-05-68.htm>. Acesso em 20 out. 2017.

Lei $n^{0}$ 12.528, de 18 de novembro de 2011. Cria a Comissão Nacional da Verdade no âmbito da Casa Civil da Presidência da República. Disponível em: <http://www.planalto.gov.br/ccivil_03/_ato2011-2014/2011/lei/112528.htm>. Acesso em 20 out. 2017. 
CARNEIRO DA CUNHA, Manuela. Índios no Brasil: história, direitos e cidadania. São Paulo: Claro enigma, 2012.

CHAMMAS, Eduardo Zayat. A ditadura militar e a grande imprensa: os editoriais do Jornal do Brasil e do Correio da Manhã entre 1964 e 1968. 2012. 112 f. Tese (Mestrado em História) - Programa de Pós-Graduação em História, Universidade de São Paulo - USP. São Paulo: USP, [2012].

CHARTIER, Roger. A História cultural: entre práticas e representações. Tradução: Maria. Manuela Galhardo. Rio de Janeiro: Bertrand Brasil; Lisboa: Difel. 2002.

CNV. Comissão Nacional da Verdade. Relatório da Comissão Nacional da Verdade. V. I e II. Brasília, 2014. Disponível em: $\langle$ http://www.cnv.gov.br/images/pdf/relatorio/volume_1_digital.pdf $>$ $\langle$ http://www.cnv.gov.br/images/pdf/relatorio/volume_2_digital.pdf $>$. Acesso em 20 out. 2017.

COSTA, Anna Maria Ribeiro Fernandes Moreira da. Senhores da Memória: história e universo dos Nambiquara do cerrado (1942-1968). Cuiabá: Univen, 2002.

DAVIS, Shelton. Vítimas do Milagre: O Desenvolvimento e os Índios do Brasil. Rio de Janeiro. Zahar, 1978.

DIAS FILHO, Antonio Jonas. Sobre os viventes do Rio Doce e da Fazenda Guarany: dois presídios federais para índios durante a ditadura militar. 2015. 244 f. Dissertação (Doutorado em Ciências Sociais) - Programa de Estudos Pós-Graduados em Ciências Sociais, Pontifícia Universidade Católica - PUC. São Paulo: PUC, [2015].

FICO, Carlos. Espionagem, polícia política, censura e propaganda: os pilares básicos da repressão. In: FERREIRA, Jorge Luís; DELGADO, Lucília de Almeida Neves (Org.). O Brasil Republicano: O tempo da ditadura., regime militar e movimentos sociais em fins do século XX, v. 4. 4. Rio de Janeiro: Civilização Brasileira, 2003. p. 167-206.

GAGLIARDI, José Mauro. O indígena e a República. São Paulo: HUCITEC, 1989.

GARFIELD, Seth. A luta indígena no coração do Brasil: Política indigenista, a marcha para o oeste e os índios Xavante (1937-1988). São Paulo: Editora Unesp, 2007.

GOMES, Mércio Pereira. Os índios e o Brasil. Petrópolis: Vozes, 1991.

GOMES, Nilo Sérgio. Em busca da notícia: Memórias do Jornal do Brasil, 1901. 2006. 183 f. Tese (Mestrado em Memória Social) - Programa de Pós-Graduação em Memória Social, Universidade Federal do Estado do Rio de Janeiro - UNIRIO. Rio de Janeiro: Unirio, [2006]. 
GUIMARÃES, Elena. Relatório Figueiredo: entre tempos, narrativas e memórias.2015. 203 f. Tese (Mestrado em Memória Social) - Programa de PósGraduação em Memória Social, Universidade Federal do Estado do Rio de Janeiro UNIRIO. Rio de Janeiro: Unirio, [2015].

HECK, EgonDionisio. Os índios e a caserna: políticas indigenistas dos governos militares (1964-1985).1996. 146 f. Dissertação (Doutorado em Ciência Política) Programa de Pós-Graduação em Ciência Política, Universidade Estadual de Campinas UNICAMP. São Paulo: UNICAMP, [1996].

JORNAL DO BRASIL. "Doenças e tiros matam um índio por dia no MT". CPDoc JB/ Hemeroteca Digital BN, 26 mar. 1965.

. "SPI quer conter o avanço sobre as terras dos índios e acusa Prelazia de cobiça”. CPDoc JB/ Hemeroteca Digital BN, 11 abr. 1965.

. "Padre afirma que brancos querem matar 7 mil índios na região XinguTapajós”. CPDoc JB/ Hemeroteca Digital BN, 23 jan. 1966.

"Diretor do SPI culpa Banco da Amazônia por massacres dos índios em Mato Grosso". CPDoc JB/ Hemeroteca Digital BN, 29 jan. 1966.

. "Conflitos acabarão quando branco não se mete com o índio, diz o diretor do SPI”. CPDoc JB/ Hemeroteca Digital BN, 16 mar. 1966.

- "Polícia Federal mobilizada para prevenir chacina de indígenas no Maranhão". CPDoc JB/ Hemeroteca Digital BN, 14 abr. 1966. 1966.

"Posseiros ameaçam índios". CPDoc JB/ Hemeroteca Digital BN. 19 maio . “Bárbaros contra índios”. CPDoc JB/ Hemeroteca Digital BN, 18 mar. 1968.

. "O nome do Brasil. Jornal do Brasil". CPDoc JB/ Hemeroteca Digital BN. 26 mar. 1968.

. “Genocídio Arquivado”. CPDoc JB/ Hemeroteca Digital BN. 28 mar. 1968.

"Govêrno prepara demarcação de terras dos índios para impedir a extinção da raça”. CPDoc JB/ Hemeroteca Digital BN, 17 maio 1968.

. “Crianças chacinadas". CPDoc JB/ Hemeroteca Digital BN, 20 maio 1968.

. “Crime Compensador”. CPDoc JB/ Hemeroteca Digital BN, 1 jun. 1968.

"PM mineira livra a tribo maxacali de extermínio por alcoolismo e grilagem". CPDoc JB/ Hemeroteca Digital BN, 7 jun. 1968. 
"Albuquerque e Lima promete devolver aos índios todas as terras tomadas à força”. CPDoc JB/ Hemeroteca Digital BN, 28 jul. 1968.

KUSHNIR, Beatriz. Cães de Guarda: Jornalistas e Censores, do AI-5 à Constituição de 1988. São Paulo:Boitempo; FAPESP, 2004.

LIMA, Antonio Carlos Souza. Um Grande Cerco de Paz: Poder tutelar, indianidade e formação do Estado no Brasil. Petrópolis: Vozes, 1995.

MAINGUENEAU, Dominique. Análise dos textos de Comunicação. São Paulo: Cortez: 2005, p.51.

PRICE, David. Before the Bulldozer: The Nambiquara Indians and the World Bank. Washington, DC: SevenLocks Press, 1989.

OLIVEIRA FILHO, João Pacheco de (Org.). 1998. Indigenismo e Territorialização: Poderes, Rotinas e Saberes Coloniais no Brasil Contemporâneo. Rio de Janeiro: Contra Capa Livraria, 1998.

RIBEIRO, Darcy. Os índios e a civilização: O desenvolvimento e os índios no Brasil moderno. São Paulo: Companhia das Letras, 1996.

SILVA FILHO, Eduardo Gomes. Projetos desenvolvimentistas na Amazônia e a resistência dos Waimiri-Atroaria (1964-2014). 2015. 215 f. Tese (Mestrado em História) - Programa de Pós-Graduação em História, Universidade Federal do Amazonas - UFAM. Manaus: UFAM, Manaus, [2015].

SMITH, Anne-Marie. Um acordo forçado: o consentimento da imprensa à censura no Brasil. Rio de Janeiro: Editora FGV, 2000.

SOARES, Gláucio Ary Dillon. A censura durante o regime autoritário. Revista Brasileira de Ciências Sociais. São Paulo, v. 4, n. 10, p. 21-43, jun. 1989.

VALENTE, Rubens. Os fuzis e as flechas: História de sangue e resistência indígena na ditadura. São Paulo: Companhia das Letras, 2017. 